\title{
Folk, dannelse og styreform: En anmeldelse af Ove Korsgaard, Kampen om folket (2004)
}

\author{
Af Vagn Wåhlin
}

Ove Korsgaard, Kampen om folket. Et dannelsesperspektiv på dansk

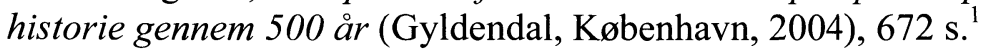

Ove Korsgaards disputatsforsvar på Danmarks Pædagogiske Universitet (DPU) var i april 2004 vel besøgt, livligt og på forhånd godt omtalt i medierne, ligesom bogen var seriøst anmeldt i en række større dagblade. Efterfølgende viste en række indlæg fra kendte debattører og kulturpersonligheder emnets brede relevans i dagens Danmark midt mellem et på ny stigende nationalt og personligt engagement i kulturel og historisk selvforståelse over for EU's og globaliseringens udfordringer, ${ }^{2}$ jf. en række eksempler i note 1.

Når disputatsen fortjener en vægtig præsentation for GrundtvigStudiers læsere, skyldes det dens tematik om: Hvad er 'folket', hvordan blev det skabt og videregivet som begreb og realitet, hvordan hænger dette sammen med dets medlemmers ændrede selvforståelse som individer i tid og socialt rum, og hvordan hænger dette igen sammen med nationalitet og fædreland, og hvordan hænger dette slutteligt sammen med styreformen fra kongedømme til folkestyre og demokrati? - alt sammen væsentlige spørgsmål, som Grundtvig selv og hans tilhængere kæmpede med og fremlagde egne bud på samlet og forståeligt for befolkningens brede lag, for eksempel i den for mange stadigt aktuelle sang "Folkeligt skal alt nu være..." fra $1848{ }^{3}$

\section{Formål og tilgange}

Alt for mange disputatser er ved snævert emnevalg og en nok hæderlig arbejdsindsats, men reelt kedeligt fremlagte og formidlede resultater endt som endnu en ufolkelig indsats, der samler støv på bibliotekernes hylder og kun for skams skyld anføres i andre forskeres fodnoter. Noget sådant gælder heldigvis ikke for denne stort anlagte syntese om begreberne og realiteterne: ethnos, folk, over for demos, befolkning, i den meningsgivende samspilstrekant af folk/befolkning, nation/stat og demokrati/selvforvaltning ${ }^{4}-$ og disses vekselvirkninger og udviklingsproces set i et 500-årigt perspektiv af skabelse, fastlæggelse og forandring fra Reformationens multietniske og multikulturelle konglomeratstat til årtusindskiftets kerneland, Danmark. Ud fra en grundlæggende - men ikke eksplicit diskuteret - antagelse af, at en- 
keltmennesket og samfundet til stadighed befinder sig mellem kaos og orden, samt at vi efterlevende faktisk kan udrede og synliggøre denne konstante dobbelt-proces hen mod på én gang stadigt øget samfundsmæssig kompleksitet - og deraf følgende kaos - og et samtidigt stigende antal af stadigt mere effektive sociale strukturer og styringsteknikker, som bringer social orden. Forfatteren spørger til, hvordan mennesket finder og udfolder en identitetsgivende selvforståelse i løbende vekselvirkning med ordensbefordrende begreber om omverdenen ( $\mathrm{fx}$ familie/slægt, kongerige, folk), der igen er i samspil med meningsfulde og genkendelige mønstre for samfundsmæssige handlinger ( $\mathrm{fx}$ hoveriydende bonde, nadverindtagende menighedsmedlem, valgdeltagende borger, kundskabstilegnende student osv.). Konkret ser han dette (s. 11) som "samspillet mellem dannelse og den politiske og kulturelle udvikling", mens de parallelle udviklinger (fx økonomien) desværre i bogen bliver nedtonet. Ved denne nedtoning af de materielle livsvilkårs og økonomiens betydning får vi for eksempel generelt ikke behandlet den markedsregulerede produktionspraksis, der ellers i mange sammenhænge har vist sig overordentlig vigtig for individdannelsen, for undervisningssystemerne, for den teknologiske udvikling og for politikken - tænk her blot på samspillet mellem industrialisering, urbanisering, naturvidenskab og teknologi over for socialisme, fagforeningerne og Socialdemokratiet i Danmark fra anden halvdel af 19. århundrede og fremad til i dag. At vi i afhandlingen får behandlet de tre sidste elementer i samspil med andre mentale, politiske og kulturelle forhold er for mig ikke nok til en nødvendig helhedsforståelse af de materielt-økonomiske og politisk kulturelle forhold i vekselvirkninger.

Generelt ser forfatteren den organiserede kundskabsformidling og holdningsdannelse, og her særligt skolen, kirken og den skriftlige sprog- og begrebsudvikling, som fundamentale faktorer i en århundredelang vekselvirkningsproces mellem (a) ikke kun disciplineringen af, men skabelsen og omskabelsen af individet - og herunder også af kroppen - som sit eget projekt og formål i en inderliggørelsesproces: fra kristelig almuesmand, slægtstænkende bonde og kongelig undersåt til nationalt bevidst, demokratisk og individorienteret person og fri borger og (b) dannelsen og omdannelsen af samfundet fra en kristen og pyramidisk opbygget husholds- og fyrstestat til et moderne politisk demokratisk, men også gennemreguleret samfund afsluttende med vor tids klasseskelsophævende og individorienterede velfærdssamfund under kraftigt politisk, ideologisk, økonomisk og stormagtsrelateret globalt pres (s. 566).

Forfatteren afstår, heldigvis, fra at fremlægge tidløse definitioner på sit begrebsapparat. ${ }^{5}$ Han ser $\mathrm{i}$ stedet dette og dets anvendelighed 
indkredset ud fra en opfattelse af, at en meningsgivende forståelse både for forsker og læser vokser frem af en løbende dobbelt-proces: dels realhistorisk udtrykt $\mathrm{i}$ det også grundtvigske kerneord - i bestemt form - kampen om ... hvor altså noget samfundsmæssigt virkeligt og væsentligt, der ikke er givet eller følger en bestemt vej, men netop løbende bliver til, struktureres og forandres i et spændingsfelt mellem forskellige sociale interesser og forskellige ideer om menneskets og samfundets struktur og ændringspotentiale og dels i den løbende ideog kulturhistoriske vekselvirkning mellem samfundsopfattelserne i indland og udland og disses virkeliggørelse i det faktiske Danmark som en virkningshistorie.

Som en, der selv har prøvet dette, ${ }^{6}$ ved jeg, hvor nemt det er at sige, og hvor svært det er at udføre i praksis: Ikke at beskrive og analysere dobbelt-processen lineært som en kæde af definitorisk fastlagte årsag-virkning forløb, men som et sig forandrende mønster, et patch-work tæppe af komplekse kronologisk og diakront konfigurerede interaktioner og vekselvirkninger. I hovedsagen er denne vanskelige og komplekse tilgang lykkedes, uden at læseren bliver helt tabt på vejen.

Det tjener disputatsinstitutionen til fremme og DPU til ære, at en sådan storslået syntese som afhandlingen, reelt en Danmarkshistorie ud fra en bestemt tematik - med alle de faldgruber, dette indebærer for fejl og mangler i detaljen og ensidighed i de nødvendige til- og fravalg i synspunkter og materiale - er antaget. Ligeledes tjener det den flittige og indsigtsfulde forfatter til faglig hæder, at han til fag-historisk debat og bred folkelig nytte har delagtiggjort sine læsere i resultaterne af sine mangeårige studier, først gennem en årrække med en serie væsentlige afhandlinger, ${ }^{7}$ og nu her i en samlet, velskrevet og trods omfanget overskuelig form.

\section{Hovedlinier, synspunkter og resultater}

Inden jeg tager faghistorisk stilling til en række elementer i bogen, vil jeg efter bedste evne give læseren en oversigt over, hvad arbejdet handler om, og de vigtigste teser og resultater. ${ }^{8}$ For at få blot nogenlunde styr på de 669 sider følges i hovedsagen bogens kronologisktematiske kapitelopdeling.

Afhandlingen er bygget kronologisk-tematisk op. Vi følger med forfatteren gennem nogle tidsafgrænsede hovedperioder eller snarere temabestemte epoker. Inden for disse epoker udredes tematisk de personligt og kollektivt (1) identitetsskabende, (2) samfundsoprethol- 
dende og (3) historisk-socialt forandrende kræfter og stabiliserende strukturer i deres konkrete samspil og modspil i samfundsudviklingen. Under iagttagelse af stadige vekselvirkninger mellem disse forhold og kræfter arbejder vi os med forfatteren frem mod en forståelse ændret over tid af begreberne og realiteterne om (I) folk/befolkning, (II) om stat/nation og (III) magtrelationer og styreformer - fra personligt kongedømme til moderne massedemokrati - hvor alle tre (I-III) fænomener medvirkede til at skabe stigende kollektiv orden og personlig sikkerhed for mennesker og samfund i en lang dannelses-proces frem mod det moderne individorienterede menneske og det moderne samfund.

Hele den efterfølgende udredning er i stadig begrebsmæssig og realhistorisk dialog med nøje udvalgte dele af hovedstrømningerne $i$ europæisk filosofi, pædagogik og samfundstænkning i epokerne og vedrørende relevante dele af den danske realhistorie.

Disse spring mellem europæiske strømninger og konkrete udfoldelser heraf i Danmark er én af bogens spændende udfordringer til læseren, men er også en intellektuel udfordring og tour-de-force, som måske vil virke fremmedgørende på en del læsere.

\section{En kristen stat, 1536-1700 (s. 35-104)}

I dette kapitel vises det, hvorledes der med Reformationen først skabtes en luthersk domineret husholds- og fødselsadelsbaseret religiøs enhed i en stadigt stærkere fyrste-stat. Middelalderens toregimente-samfund mellem kirkens sværd og kongemagtens sværd ophævedes. Kirken var fremover ikke kun som ydre institution, men også som trosformidler direkte underlagt fyrstelig magt og tilsyn. Et pyramidisk indflydelses- og ansvarssystem byggedes i princippet op som en husstand og fuldendtes under den tidlige enevælde. Herefter var husbond som leder af husholdet ansvarlig for sine karle og familie, skipper for sine søfolk, mester for sine svende osv.

Trods stigende international handel fra voksende byer i samstaten som Bergen, Flensborg, Altona, Charlotte Amalie, men først og fremmest fra København - hvilket urbane udviklingsperspektiv desværre nedtones i afhandlingen - så var og forblev den agrare sektor, hvori $80-90 \%$ af befolkningen levede, med dens adelsdrevne godser og gårdmandsbeherskede landsbyer den dominerende i økonomien lokalt og rigsomfattende. I landsbyen med det sociale netværk, fællesdriften på markerne og med kreaturerne i udmarken, på landsbystævnet med de fælles beslutninger om arbejde, ordenshåndhævelse osv. formedes dagligdagen og dagliglivet for folk og fæ, så det sad i rygraden fra vuggen af, og ingen forklaring behøvede. I sognekirken, i 
menighedslivet med katekismus og salmesang og med tiden gennem en ikke-skolebaseret og dog ret udbredt læsning på print og i bog, dannedes den anden del af mennesket, af almuen og bonden, - dér, lokalt, havde han rod, derfra hans verden gik. Reformationens brede gennemslag i befolkningen var det første store offentligt organiserede folkeoplysningsprojekt, som lykkedes (s. 101), og som samtidigt forenede en religiøs og socialt normsættende dagsorden for det gode menneske og et ordentligt samfund. Verdensanskuelsen - og dermed også samfundsforståelsen - fra kongen og ned til bonden forblev religiøst funderet til midten af 1700 -tallet.

\section{Fra kristen stat til national stat, 1660-1864 (s. 105-305)}

Enevælden (1660-1848) betød en samling i en godsejer- og fyrsteligtbureaukratisk skatte- og enhedsstat med al magt i praksis uddelt fra toppen og ned. Men fra sidst i 1700-tallet delegeredes stadigt flere forvaltningsopgaver ud til lokalbefolkningen, ligesom regeringen faktisk tog hensyn til kløgtigt formulerede opfattelser i den voksende presse og offentlighed fra sidst i 1700-tallet med den opinionsstyrede enevælde.

Folk, som delbetegnelse i for eksempel folkehold, fandtes nok, men det var ikke nogen politisk eller kulturel samle- eller hædersbetegnelse. Befolkningen var opdelt $\mathrm{i}$ stænder af adel og borger, præster og bønder, hvor alle fra alle samfundslag og stænder og fra alle geografiske landområder var kongens loyale undersåtter, og hvor godsejeren havde sine fæstebønder under sig og præsten sine sognebørn og bonden sine tjenestefolk og købstæderne deres eget underordningssystem i købmandsgårde og håndværksvirksomheder. Men det var ikke, som tidligere ofte beskrevet, noget statisk system - selvom H. C. Andersen m.fl. fremhævede "Skomager bliv ved din Læst". Uddannelse via udbredt læsekundskab for de bogligt begavede sammen med oparbejdet formue for handelstalenter og egen håndværksvirksomhed for mester-svendene i købstæderne samt forfremmelser for søfolk i flåden og soldater i hæren kunne bryde det strukturelt fastlåsende samfundsmønster $\mathrm{i}$ en social opstigningsproces - og gjorde det i langt højere grad end tidligere antaget. Ligeledes flyttede menigmand langt mere rundt, end lovgivning som stavnsbåndet har ladet formode. Dette aspekt med det delvist fleksible samfund, ændringsmulighederne, kunne være nøjere behandlet gennem afhandlingen.

Den europæiske debat bragte nye opfattelser i spil i Danmark, hvorefter legitimiteten for samfundsstyret og suveræniteten langsomt 
gled fra den af Gud indsatte enevældige fyrste og over til folket, ethnos, eller befolkningen, demos. Dette betød, at folket/befolkningen måtte fastlægges som social og politisk størrelse og da med rettigheder og pligter. Det sidste indebar blandt andet et eget ansvar for at følge lovene, at yde skattebetaling og militærtjeneste m.v. mod efter økonomisk evne, køn, alder, uddannelse osv. at få borgerlige rettigheder som stemmeret, valgbarhed og mulighed for at sidde i lokale og nationale nævn og råd samt at have taleret ved offentlige møder og frit kunne formulere sig på tryk. Men da samfundet herefter bestod af borgere, der var individer, så måtte enkeltmennesket/individet også fastlægges begrebsmæssigt og i praksis, hvis socialt kaos skulle undgås. Enkeltmennesket måtte således dannes eller formes gennem systematisk opdragelse og uddannelse til et kundskabsfuldt, ansvarsbevidst og etisk dannet individ, en fuldgyldig borger.

To hovedveje stod åbne og måtte afklares. Individdannelsen og borgerretten kunne bygge enten (a) på det foelles i historie, kultur, afstamning og sprog inden for et givet landområde, dvs. etnicitet og folk, hvilket ikke passede særligt godt til konglomeratstaten Danmark op til 1864 eller (b) på stats- og samfundsdannende institutioner som i Schweiz, der afstak rammerne efter statsborgerskab og politisk engagement og ikke efter sprog og kultur, dvs. efter den aktuelle befolkning af loyale statsborger, demos.

Folkesuverænitetstilhængerne talte om fædreland og modersmål, kongetroskab og folkestyre, mens de andre talte om konstitution, føderation og demokrati - ofte med et strøg af republikanisme. Det centrale var, at man i Danmark o. 1800 ikke fik en afklaret forståelse af samlebegrebet nation og dets relation til folk, stat, borger og samfund. Fra 0.1840 blev dette problematisk med de stigende tyske og danske nationalbevægelser og skabelsen af en historisk og romantisk nationallitteratur m.v. På universitetet overtog humaniora en række dannelsespotentialer fra teologi, ofte med ordet nordisk som kendemærke, mens de stadigt flere seminarieuddannede lærere i almueskolen efter 1840 og især efter 1870 fastlagde en undervisning lokalt for folket, der var kristen og dansk, men ikke i dagligdagen centralstyret fra København. ${ }^{9}$

Sprogligt var der frem til 1864 ikke tale om nogen kulturel dansk dominans eller dansk-præget enhedsstat. Latin var de lærdes sprog, tysk var handelens og militærets sprog, mens dansk, bygdemålsnorsk, islandsk, færøsk, frisisk og plattysk var bøndernes og småkårsfolks lokalt talte sprog rundt om i riget. Tysk og dansk var de officielle skriftlige sprog, der grammatisk og i staveform blev fastlagt fra midten af 1700-tallet, og i dele af hverdagslivet (i kirken, for retten, i skolen m.v.) udgjorde tysk og dansk en slags højsprog. Skriftsproget lå og 
ligger endnu i dag i praksis langt fra menigmands sprog, skønt der efter radioens og TVs fremtrængen klart er sket en sproglig ensretning. Alligevel blev sproget både i Tyskland og i Danmark fra 1840'erne og fremover i stigende grad anset for det naturlige - det vil sige det indiskutable - grundlag for socio-politiske enheder og stater. Den pædagogiske debat blomstrede, og mange skoleforsøg sattes fra sidst i 1700-tallet og fremover gennem 1800-tallet i værk. En offentlig skoleordning blev langsomt bygget op fra midten af 1700-tallet - og var fra 1814 landsomfattende - på kristent og lokalt grundlag og omfattende både drenge og piger. Grundet offentlig pengemangel tog det tid - til o. 1840 - inden de gode intentioner med almue-skolen kunne realiseres. Da havde Grundtvig og hans tilhængere allerede søsat et nationalt projekt med at få almuen til at betragte sig selv ikke som almue, men som kernen i samfundet med en kulturel og politisk integritet og i bestemt form som folket. Kirkens præster blev i stigende grad inddraget $\mathrm{i}$ den offentlige administration ved siden af godsejerne og valgte ofte at udtrykke en kristen-national ethnos for at styrke deres indflydelse, men også ofte af ærlig overbevisning.

Scerligt i København mærkedes i 1700-tallet den økonomisk florissante periodes urban- og handelsmæssige fremgang, mens kulturlivet blomstrede og oplysningstankerne bredte sig i videnskab, administration, undervisning og retsvæsen. Indfødsretten fra 1776 (dvs. at statens embeder blev forbeholdt det danske riges statsborgere) stod her som en klar mærkesag.

Moderniseringen bed sig for alvor fast efter 1750; men stadigt boede $0.80 \%$ af befolkningen på landet, og den agrare økonomi var helt afgørende for den dansk-norsk dominerede samstat, til tabet i 1814 af Norge, men også efter dette tab. Det store kompleks af landboreformer $1788 \mathrm{ff}$. sluttede med skolelovene af $1814 \mathrm{og}$ omlagde både produktionsformer, jord-ejendomsret og klasserelationer med skabelsen af en ny middelkasse af gårdmænd, der i stigende grad i 1800tallet øvede indflydelse på næsten alle samfundsområder, undtagen i den fra 1870-90 fremvoksende urbant-industrielle sektor.

\section{Fra helstat til nationalstat (s. 268-304, s. 580-82)}

Skønt det i København gik rimeligt fredeligt for sig at gennemføre overgangen fra centralistisk enevælde til konstitutionelt demokrati, så medførte den uafklarede situation omkring ethnos og demos og de sprogligt-nationale spændinger en blodig borgerkrig mellem Danmark og de danske på den ene side og de tysksindede slesvig-holstenere på den anden side. Her lægger forfatteren sig op ad de senere års 
afvisning af, at regimeskiftet 1849 nu også gik så fredeligt for sig endda. Reelt nedtonedes først disse indre sociale og især nationalpolitiske spændinger med borgerkrigens anden omgang i 1864, hvor Preussen militært skar igennem og snart indlemmede hertugdømmerne i den preussiske stat og dermed omdannede Danmark til Europas reneste nationalstat.

Med implementeringen af den borgerligt-demokratiske middelklassestat og dets civile samfunds styrkelse ved fastlæggelsen med grundloven 1849 af de borgerlige rettigheder og pligter samt det lokale selvstyres stærke rammer var grunden lagt til et indre opgør om endnu to store og landsomfattende politiske spændingsfelter: først omkring den hidtil af nationale grunde nedtonede sociale klassekonflikt, med især gårdmændene i fremgang, dernæst kampen mellem land og by om, hvilken sektors interesser der skulle dominere udviklingen.

Her bliver den generelt manglende økonomiske dimension i afhandlingen særligt tydelig - og derfor de følgende linier herom:

Uden at fă fastlagt - med landbrugseksporten som grundstammen i den nationale økonomi - dels gårdmandsklassens økonomiske styrke potentielt og fra 1850 'erne reelt ved at sidde på $0.75 \%$ af den produktive jord og dels dens evne og tillærte færdighed til kollektiv indsats lokalt, produktionsmæssigt, afsætningsmæssigt og vedrørende finansiering (andelsbevægelsen), så forstår man ikke mulighedsbetingelserne for deres kulturelle, oplysningsmæssige, politiske og dansk-nationale indsats, der i bogen er i centrum (s. 189-323), men i teksten er delt over to epoker. Økonomisk slog den kapitalistiske markedsøkonomi igennem i Danmark o. 1840 også i agrarsektoren. I tiden 1840-70 etablerede gårdmændene sig i stigende grad som en agrar middelklasse med fra 1870-1901 stærkt øget indflydelse og et stigende selvværd. Højskolesangbogen som ideologisk opbyggelsesværk har mængder af eksempler på, at gårdmændene fra 0.1870 så sig selv som grundstammen i folket (ethnos). Baseret på et imponerende og effektivt samarbejde i politik (Venstre og aviserne), i økonomi vedr. produktion og salg (andelsbevægelsen), i kultur og uddannelse (fri- og højskolerne, forsamlingshusene), i finanssektoren (sparekasserne, egnsbanker, kreditforeninger), i ungdomsbevægelser, i husmoderforeninger m.v. fik denne agrare middelklasse fra 0.1870 sat sig så effektivt på samfundsudviklingen og landets generelle selvforståelse, at denne indflydelse holdt sig til o. 1970, længe efter at landbrugets - og hermed gårdmændenes - relative økonomiske bidrag til den samlede samfundshusholdning var kommet stærkt på retur. ${ }^{10}$

Mens denne økonomiske forståelse af gårdmandens placering i den folkelige, danske og nationale selvudvikling har betydning i mere end 100 år, så træder industrialiseringens og urbaniseringens arbejdere 
først for alvor i karakter fra o. 1890 og godtager sig selv som en ligeberettiget del af det folkelige Danmark fra o. 1930. Hvilket nøjere behandles i bogens næste afsnit om:

\section{Den demokratiske nationalstat (s. 307-467)}

Kronologisk med temaer om "Embeds- og godsejerstaten 1848-1901", "Venstrestaten 1901-29" og "Socialstaten 1929-1972" træder det moderne klassesamfund i karakter med borgerskab, gårdmænd og arbejdere i rækkefølge som opbyggende, overtagende og videreformidlende et personligt og kollektivt ansvar for samfundsudviklingen og over for medmennesket, individet. (1) Staten og det offentlige over for (2) markedet og (3) det civile samfund, disse tre elementer står for forfatteren i stadig vekselvirkning og interessekonflikter med hinanden i den fra 1864 frie demokratiske samfundsorden. I denne orden må enkeltmennesket til stadighed finde sin plads og identitet som borger, producent/forbruger og individ. Folket er fra $0.1850 \mathrm{og}$ fremover i en række sammenhænge blevet det identitetsskabende kerneord i egen- og samfundsforståelsen.

Folkehøjskolen blev og er stadigt et vigtigt element i skabelse, opretholdelse og transformation af det politiske, det sociale og det kulturelle folkebegreb, som forenes og brydes i sammenkædningen folk og nation. Alligevel må vi med Korsgaard huske, at der hele tiden har været en faktisk skillelinie mellem de mere landbrugspraktik formidlende højskoler og de mere folkeligt nationale og ideologiske højskoler.

Efter den nationalliberale magtovertagelse (1848-64) skulle statskirken blive til en folkekirke, kongens hær og flåde til et nationalt forsvar, lovgivningen udspringe af et folketing og et landsting m.v. Men dette var ikke nok for grundtvigianerne, der pressede på og fik en forældrestyret friskole, valg- og frimenigheder for religionsudøvelse osv. i en proces, hvor bindestregen folk(e)- næsten tog patent på det, som i Europas liberale opfattelse stod for civilsamfundet. De nationalliberale og dermed embedsmændene primært i København urbansektoren - tabte med nederlaget 1864 legitimiteten som bærere af den nationale stat. Den agrare sektor med godsejere og forskellige grupperinger af gårdmænd - med grundtvigianerne som ideologiskfolkelige bannerførere - tog politisk over. Igen her må læseren i bogen efterlyse en klarere forståelse af de dybe forskelle mellem land og by, ikke kun geografisk-økonomisk, men også socialt, kulturelt og politisk, der eksisterede i Danmark på den tid og helt op til efter Anden Verdenskrig. ${ }^{11}$ 
Kampen om folketingsparlamentarismen ca. 1875-1901 har klare træk af ikke blot demokrati som folkestyre over for et autokratisk godsejerstyre, men også af land imod by. Det lykkedes for de konservative som partiet Højre i byerne fra 1880'erne politisk at organisere de mange mindre selvstændige næringsdrivende på deres side, men disse var sandelig også nationale. Preussen, og andre europæiske magter senere, havde fra o. 1840 spændt nationalismen for deres ekspansive udenrigspolitik og nationale samlingspolitik. Og også i Danmark fik vi nu to slags nationalisme: en mere konservativ med vægt på Gud-konge-fædreland og en mere venstrepræget med vægt på folket, naturen, landsbyen og de lokale forhold og ofte med klart antiurbane og antikapitalistiske træk, hvilke sidste 'antier' læseren må efterlyse nøjere behandlet.

I 1901 sejrede folketingsparlamentarismen med J. C. Christensen som leder og ham selv som kultusminister. Herefter blev kirken og skolesystemet demokratiseret med menighedsrådsvalg og indførelse af en $\mathrm{i}$ mange år vellykket mellemskole mellem den kommunale almueskole (først ophævet 1937) og gymnasiet, der stadigt forberedte til de højere uddannelser, som ikke var, men med tiden blev nationale.

Efter Preussens magtpolitiske dominans bestod Danmarks reelle forsvar for nationalstaten af ikke et militært, men af et kulturelt forsvar (jf. Sønderjylland) forbundet med total neutralitet. Den europæiske og kulturradikale linie fra Brandes og Politiken fra 1880'erne med en ny modernitet betød reelt en trussel mod den grundtvigske folkeforståelse som kernen i en national og personlig identitet.

Efter arbejderbevægelsens første turbulente år og klassesolidariske identifikatoriske linie måtte bevægelsen afklare sig i forhold til problemstillingen: national/international. Med Første Verdenskrig blev en afklaring helt uomgængelig, og her sejrede den nationalt folkelige linie. I Skandinavien søgte socialdemokratierne en blødere og nationsafgrænset linie, mens Finland under indtryk fra Ruslands revolution 1917 røg ud i sin første blodige borgerkrig. ${ }^{12}$ Men fredsslutningen manifesterede endnu et problem omkring sprogligt-nationale minoriteter og deres demokratiske rettigheder (s. 411 f.): skulle mindretallene have kulturelt-sprogligt og evt. regionalt selvstyre i en føderativ styreform som i Schweiz, eller skulle de reelt via skole m.v. assimileres ind $\mathrm{i}$ den dominerende nation (den amerikanske og franske model), eller skulle de tvangsforflyttes (Lenin/Stalins model, Grækenland/Tyrkiet) eller helt udryddes (Hitlers model). For første gang i 140 år er Danmark nu med den muslimske masseindvandring i en situation med lokale tæt-områder, hvori store dele af befolkningen aktivt ikke ønsker - eller vanskeligt lader sig assimilere ind i - 'det danske', det vil sige dette at blive og være en del af 'folket', religiøst, 
politisk, sprogligt, kulturelt, ægteskabeligt m.v. ${ }^{13}$ Derfor dukker i Danmark, som mange andre steder i Europa, modellerne fra 1920'erne naturligvis nu o. 2000 igen frem i debatten som indlæg om mulige og relevante løsninger med en kun let moderniseret og humaniseret overflade.

\section{Socialstat og velfaerdssamfund 1929-72 (s. 417-467)}

Socialdemokratiet og arbejderbevægelsen - i samvirke med husmandsbevægelsen - tillægges med rette æren for at have udbredt blandt arbejderne og fået implementeret i love og samfundsudvikling den moderne velfoerdsstat omfattende alle, det vil sige hele befolkningen og dermed en sammensmeltning af ethnos og demos. Socialstaten omfatter i princippet alle, fra vugge til grav, mænd og kvinder, håndens og åndens arbejdere, velstående som fattige, osv.

Styrken i de grundtvigske højskoler gjorde indtryk på arbejderbevægelsens kulturelt bevidste ledere og førte til en kulturel klassekamp bl.a. ved efterligning af grundtvigianerne med arbejderhøjskoler, aftenundervisning, forlag osv. Den socialt bevidste lighedsdimension blev efter 1945 blandt andet af Hal Koch sat i en ny interaktiv trekant af 'social', 'national' og 'demokrati' til afløsning af agrarsamfundets gamle forbindelse af folk, kultur og stat. Den stadigt eksisterende ulighed mellem danskerne, frembragt af blandt andet markedet og økonomien, men også skæve uddannelsesbetingelser, måtte søges og blev politisk og socialt udjævnet via statsmagten og grebet om denne.

Parallelt hermed søgtes efter Anden Verdenskrig gennem en internationalisering af Menneskerettighederne og en magtafbalancering af staterne gennem $\mathrm{FN}$ en sikring af individets ret over for befolkningernes og staternes ofte uhæmmede magtmisbrug over for egne medborgere og udefra kommende flygtninge og indvandrere.

I perioden 1848-1972 har isme-begreberne nationalliberalisme, grundtvigianisme, kulturradikalisme og socialisme med flere ismer alle søgt at tage patent på den rette forståelse og konkrete klassebaserede gennemførelse af et folk af individer i en demokratisk nationalstat. Først med Anden Verdenskrig nåedes det nationale og folkelige kompromis, der samlet førte til den moderne velfærdsstat.

Fra nation-stat til en føderation af nation-stater, 1972-2000 (s. 469-565)

I dette afsluttende hovedafsnit er der løbende foretaget den meningsgivende kobling mellem økonomi og produktion i relation til individ- 
dannelse og samfundsskabelse, som er efterlyst i flere tidligere dele af bogen.

Med Danmarks indtræden i EF (EU) 1972 finder forfatteren et afgørende vendepunkt begrebsligt og i historisk virkelighed for landet. Folk/folkelighed har i stigende grad i den sidste menneskealder tabt sin positivt værdiladede betydning, mener han. Men forfatteren mangler så at forklare læseren, hvorfor de bedst begavede politikere på stribe har knyttet sig selv til navne som 'Socialistisk folkeparti', 'Kristeligt folkeparti' (nu Kristen-demokraterne og måske derfor på vej ud), 'Dansk folkeparti', mens af rent politiske konnotationer som 'demokrater' eller 'parti' 'Centrum demokraterne', 'Fremskridtspartiet' og 'Kristendemokraterne' har det skidt med vælgertilslutningen, ligesom Venstre diskret skjuler, at det også hedder 'Danmarks liberale parti', og de konservative aldrig selv glemmer at anføre 'Det konservative folkeparti'. Socialdemokraterne er hidtil sluppet godt fra ikke at have 'folk' i deres navn, men deres stadigt mest populære slagsang fra 1934 begynder og ender dog med Danmark for folket. Og alle politikerne kæmper livslangt og indædt om og udfolder sig i Folketinget, mens Europa-parlamentet er rigtigt fjernt og ufolkeligt. Det værste, vore politikere ved efter en stor politisk tale, er at blive kaldt ufolkelige ${ }^{14}$ Ofte er det for analytikere klogt at se på, hvad mennesker absolut ikke vil benævnes, for at udrede, hvad de så faktisk ønsker at fremtræde som. Folk, som ethnos, er så absolut ikke i det 3. årtusinde et positiv-ord på vej ud. Tværtimod er folk sammen med ord som land/flag, kongehus, lokal/egn, natur, miljø og havnefront så stærkt identitetsdannende som nogensinde stillet over for begreber om og realiteter af usynlig edb-centralisering, synlige muslimske indvandrere, usynlig EU-dominans, usynlig, men mærkbart omklamrende globalisering som oftest uden for nogen regerings kontrol osv., hvilke sidste elementer efterlader mange i tvivl om deres identitet, om deres selvvalg og selvforståelse kun på overfladen er selvvalgt og reel.

Derimod har forfatteren ret i, i sidste afsnit, at påpege den afgørende ændring, der ligger $\mathrm{i}$, at den hidtidige folkeligt/nationalt grundede fællesforståelse for samfundets udvikling ikke længere har nogen bærende klasse at støtte sig til. Via EU-domstolens kendelser og EUadministrationens direktiver tilrettelægges danskernes hverdag i stigende grad uden for deres egen og deres politikeres reelle indflydelse - føderalismen tager over. Og, kunne forfatteren tilføje, ved frivillig tilslutning til en række humane konventioner med særlige domstole og tilsynsråd gælder det $\mathrm{i}$ stigende grad ikke længere, at $i$ Danmark bestemmer danskerne. Men hvem bestemmer så? Har magtens udøvere - og måske dermed vores reelle fjende - et ansigt? Kan individet og folket med de kendte identiteter og handlingspo- 
tentialer overhovedet forholde sig til og bekæmpe de bevidst usynlige modmagter, for eksempel i markedsøkonomiens børstransaktioner og i terrornetværkenes cellestrukturer i internettets virtual reality. Med forfatterens afsluttende trosbekendelse til 'folkets' eksistens og relevans må læseren håbe på, at han i sin samfundsmæssige praksis vil gøre sit til, at bærerne af økonomismens, globalismens, postmodernismens og multikulturalismens ${ }^{15}$ pseudo-ideologier ikke sejrer.

Fra 1970'erne er den internationale trend, at det industrielle samfund afløses af det postindustrielle produktionssamfund, og det moderne samfunds projekt med at skabe fælles forståelser og referencerammer går $\mathrm{i}$ opløsning $\mathrm{i}$ den multikulturelle og postmoderne udvikling. Industrisamfundets stigende produktivitet hørte sammen med en stadigt forfinet arbejdsdeling, men o. 1970 blev det klart, at stadigt øget viden fremover ville blive grundlaget for en øget produktivitet. Det nye videnssamfunds spredning og effektivitet medfører (s. 548) grundlæggende et samfund i løbende transformation som: det lærende samfund, den lærende organisation og det lærende individ. Informationsteknologiens eksplosive ekspansion de sidste 20 år tillader allerede via computere og netværk en vidensproduktion og spredning deraf uden for staternes og universiteternes og virksomhedernes reelle kontrol og systematisering - jf. terrorbevægelsernes effektive udnyttelse heraf. Kun barneskolen synes at ville holde en tid endnu, mens grænsen mellem uddannelsesinstitution, samfund og nationalstat og individdannelse er i opløsning.

Religionens og religiøsitetens genkomst i Danmark og mange andre steder i det offentlige rum fra 1990'erne kan synes en mærkelig konsekvens af den vellykkede, bevidste og ubevidste, sekulariseringsproces og multikulturalisme i skole og samfund. Måske ligger der heri ifølge forfatteren et ønske om ikke at modernisere kristendommen, men om at kristne/islamisere moderniteten (s. 509) i en ny postmodernistisk forståelse af forholdet mellem stat, religion, politik og borger/individ.

Over for EU's og globaliseringens stærkt national-opløsende kræfter peger forfatteren på problemet, om reelt demokrati i Europa kan fungere føderativt uden at være knyttet til et ethnos, en identitetsgivende folkeforståelse, der er bundet til en vis fælles kultur, en smertefuld, men dog fælles historie, en trods trosforskelligheder dog fælles kristendom, en nogenlunde fælles forståelse af det repræsentative demokrati m.v. Det kan her undre, at forfatteren ikke medtager styrken i fjendebilleder; vi (dvs. flertallet) er ikke muslimer, vi går ind for at behandle kvinder som lige medborgere, vi sætter ikke kirkens (dvs. Koranens) love over statens love, osv. For mig at se er denne 
accept af fjendebilleder i fuld gang og det med stigende styrke - og heri desværre hjulpet godt på vej af mindre, men højprofilerede islamiske ekstremistgrupper - både i Danmark og i resten af Europa. Dermed styrkes den historisk og antropologisk kendte personlige og kollektive identitetsdannelse via modbilledet; men samtidigt svækkes de positivt sammenbindende kræfter i samfundet, i kærlighed, eller som Gundtvig formulerede det allersidst i sangen "Folkeligt skal alt nu være" i 1848, ..."Dansk er immer Kicerlighed.", jf. note 3.

Mindre i den skønlitterære og fortidsbeskrivende produktion, men mere og stærkt $\mathrm{i}$ den allernyeste litteraturforskning og fagvidenskabelige historieskrivning ses en retning hen imod at betragte den nationale ramme som ikke-relevant, blandt andet fordi rammeforståelsen naturligvis ikke er noget én gang fastlagt, men selv er et kulturelt produkt, der ændrer sig over tid og rum. Både universiteterne og folkehøjskolen har indrettet sig efter denne ændring, så Højskolesangbogen ikke længere som en naturlighed skaber en fælles forståelsesramme og Danmarks stats- og samfundshistorie ikke i sig selv legitimerer forskning og undervisning på universitetet. ${ }^{16}$

I folkeskolen er undervisningen i sin uundgåelige holdningsbearbejdelse af børnene gået fra en national og kristelig linie til en demokratiserende, antiautoritær, elevorienteret, international, menneskerettighedsfremmende og naturbevarende holdningsbearbejdelse i skolens hverdag med færdighedstilegnelse og selvlæring som centrale elementer. I reaktion mod denne dominans har mange forældre, i 2003, op mod 13\%, stemt med fødderne og flyttet deres børn fra den offentlige til den frie skoleverdens ofte mere ideologisk og pædagogisk bevidste institutioner. Det centrale er, her efter år 2000, at der ikke længere eksisterer et tilstrækkeligt bredt accepteret sæt af værdier i Danmark, som en klar majoritet af befolkningen kan tilslutte sig som grundlag for skolen, og dermed som basis for individdannelsen, når vi samtidigt vil hævde den enkeltes ret til egen standpunkttagen og eget handlingsmønster; det samlende ved friskoletilgangen manifesteres $\mathrm{i}$ disse år - for mig at se - mere ved det, forældrene i protest ikke kan lide ved samfundsudviklingen og folkeskolen. Med ovennævnte livslang træening og læring som kerneord er, efter Korsgaard, fokus i videnstilegnelsen flyttet fra skolen i samfundet som institution og over til den enkelte, individet, som både ansvarlig og normsætter i stigende afhængighed af computer og ITnetværk.

Men hvor bliver det historisk, kulturelt og identitetsskabende folk af i den proces? Og hvad med demokratiet? På bogens allersidste linier advokerer forfatteren for, at begrebet folk stadig er meningsgivende ikke kun som omhandlende en fortid, men også for nutiden og 
fremtiden, hvis vi erindrer os, at mennesket kan føle sig omsluttet af flere identiteter og verdensanskuelser på én gang og her altså både kan være europæer og dansker såvel som verdensborger - heri er jeg ganske enig.

For anmelderen er det menneske- og samfundsanalytikerne - de humane og sociale videnskaber - der har et problem med flere parallelle individuelle og kollektive identiteter i spil på én gang, og ikke nødvendigvis det faktisk levende menneske. Det er for mig politikerne og politiserende akademikere og missionerende religiøse ledere, som over århundrederne har bildt dele af befolkningerne ind, at én religion udelukker andre, at ét folk og ét sprog udelukker andre, at én familiestruktur udelukker andre, og at én økonomiform - markedsøkonomien - nødvendigvis udelukker andre. Og det er den allestedsnærværende tendens til at forstå os selv gennem forskelligheden fra andre, dvs. en selvskabelse og godtagelse af fjendebilleder, som for mig er en af de stærkeste drivkræfter i identitetsdannelse og samfundsforandringer men dermed også i konflikter og krige.

\section{Nogle punkter til debat}

Symbolske og imagincere forestillinger - og realiteterne: Lad mig først gentage en tidligere bekendelse: Menneskene handler ikke efter, hvordan virkeligheden er beskaffen, men efter hvordan de tror, virkeligheden er skruet sammen. Når tilstrækkeligt mange deler opfattelse angående omverdenens beskaffenhed, så vil de i vigtige spørgsmål handle derefter og følgelig opretholde eller ændre på denne samfundsmæssige - også for andre iagttagelige - virkelighed. Men derved ændrer 'troen' karakter til en rent fysisk virkelighed, Jerichos mure er faldet, en kirke er bygget, Amerika er befolket. For at få styr på 'symboler' i en samfundsforståelse, for eksempel af Dannebrog, kan det være nyttigt med at opstille 'symbolske ordener', såsom kronen for kongemagt og stat, korset for tro og kirke og fanen for det danske og hele Danmark, og så udrede disses indbyrdes relationer om, hvornår og hvordan disse symboler fik klare relationer til den samfundsmæssige virkelighed. Men i sådanne processer fik og får symbolerne selv meningsgivende og handlingsstyrende karakter, og dermed blev og bliver de til reel virkelighed, når konkrete mennesker rettede sig efter deres mening og betydning: når fanen rejstes over ravinen, $\mathrm{og}$ soldaterne gik frem og kæmpede, så døde de selv og fjenden blodigt og smerteligt, og det var reelt og ikke symbolsk, og nye politiske og sociale realiteter kunne fremstå heraf - selvom nogle af dem senere kunne blive mindet $i$ en sang med symbolsk værdi. 
Når et menneske ændrer selvforståelse og herunder bliver til et nyt individ, så ses dette blandt andet $\mathrm{i}$ ændrede adfærdsmønstre og ændrede relationer til andre, det vil sige $i$ en samfundsmæssig virkelighed, der også reelt kan ændres netop ved individets ændring og vice versa. Rekrutten bliver i slaget til soldat, der i konkrete kampsituationer kan sætte livet ind for at redde en kendt, en kammerat; men det er sjældent han sætter livet ind for en uvirkelighed, et symbol som for eksempel Stars-and-Stripes, selvom det sker.

Skabelsen af folket, som en real kulturel og historisk proces, skabte også en samfundsmæssig ny virkelighed, der var med til at ændre mange menneskers selvopfattelse og prægede deres handlingsmønstre inden for rammen af deres forståelse af at være en del af folket og have skæbnefællesskab med dette. Det synes jeg, forfatteren har analyseret og beskrevet godt og fremlagt relevant; men jeg kan ikke se, at Korsgaard afgørende har udredet nytten af omvejen over den symbolske orden, for slet ikke at tale om de i nationalismeforskningen tidligere så populære 'imaginære fællesskaber'. Hvis noget kun er symbolsk, for slet ikke at tale om imaginært, men ikke flytter på eller opretholder eller nyskaber virkeligheden, så har det for mig at se kun spekulativ filosofisk eller idehistorisk relevans, som middelalderens spørgsmål om, hvor mange engle der kunne danse på en nålespids. Altså, jeg er enig med Korsgaard (s. 29-31) i sprogets og begrebernes samspil med menneskets faktiske handlingsmønstre, hvad er muligt og især umuligt - at tænke og derefter omsætte til handlinger $i$ en given samfundstotalitet. Jeg er ligeledes enig $\mathrm{i}$ det frugtbare $\mathrm{i}$ at se fortællingen som central $i$ menneskelig social omgang og identitetsskabelse over for et mere rationelt sprog $\mathrm{i}$ handlingens dimension. Magten, som evnen og viljen til at få andre til at rette sig efter magthaverens udtrykte eller formodede ønske, er ved siden af demokrati som styreform og livsform nødt til at blive synliggjort for at virke. Men er der ved inddragelse af magten tale om en symbolsk (s. 31) eller en reel orden? For mig at se er mit møde i torskegildet med statens og kommunens skattevæsen eller politiets konkrete færdselsanvisninger aldeles ikke symbolsk og slet ikke imaginært, men såre virkeligt og økonomisk ganske smertefuldt.

Forfatteren er selv en god fortæller af de lange linier og af de mange små fortællinger, som giver liv og mening til den store historie. Det er en fornøjelse at læse denne bog om folk, nation og demokrati.

\section{Håndvarket $i$ arbejdet og fremlaggelsen}

En disputats er også et opslagsværk for fagfolk og studerende vedrørende henvisninger og benyttet litteratur. Det medtagne er impone- 
rende, men desværre behæftet med for mange fejl og mangler, som næppe ville blive accepteret $\mathrm{i}$ et hovedfagsspeciale $\mathrm{i}$ historie. Blot nogle få eksempler herpå (det manglende, forkerte, er understreget), som jeg kunne finde $\mathrm{i}$ mit eget håndbibliotek uden elektronisk søgeteknik: (1) Hans Bekker-Nielsen (red.): Svend Grundtvig: Danskeren paa Farøerne Sidestykke til Tysken $i$ Slesvig (1845), Odense Universitetsforlag, 1978, med Efterskrift af Hans Bekker-Nielsen; (2) Vagn Wåhlin (red.): "Nik. Frd. Sev. Grundtvig: Politiske Betragtninger med Blik paa Danmark og Holsteen", Grundtvig-Studier, 1994, s. 1658, (med noter af V. W. og direkte efterfulgt sammesteds af) Vagn Wåhlin: "Grundtvig i politik op til 1830", s. 59-91. Både BekkerNielsens efterskrift og Wåhlins noter og artikel må ifølge Korsgaards tekst være benyttet af ham. En sprogkyndig korrekturlæsning af citater, titler m.v. havde været nyttig, hvorved mange 'å' for 'aa' og andet fra tidligere stavemåder kunne være undgået eller (Korsgaard 2004, 649) Roar Skovmands disputats fra 1944 ikke ville være blevet sat til at omfatte tidsrummet 1841-1992, men rettelig til 1841-1892, osv.

Ikke alle behersker lige let fransk, derfor er det som med Rousseaus skrifter i bogen (samt tre af Foucault) ofte bedre at gå til danske udgaver. Herved får forfatteren blandt andet direkte citerbare udpluk, og det er sikrere end ved at gå vejen over engelsk, hvor muligheden for misforståelser fordobles. Foucault har altid udtrykt sig snørklet på fransk, bl.a. fordi han ville have læseren med over i nye forståelser fra starten og derfor forkastede mange gængse franske sproglige udtryk fastlagt inden for den herskende litterære og videnskabelige tradition. Men i stedet for konsekvent at benytte de mange danske, norske og svenske oversættelser af Foucault, så holder Korsgaard sig på væsentlige felter til engelsksprogede oversættelser, hvilket blot giver mulighed for nye problemer, blandt andet fordi Foucaults konstant skiftende tankeverden og udtryksform ikke egner sig særligt godt for en engelsk sprogform.

Det er for læseren, for at få noterne med, slemt i tidsskrifter at skulle slå om bagest $i$ artiklen, men man overlever dog. Når læseren som her har 669 sider at gå fejl $\mathrm{i}$, så bliver fingrene direkte blodige ved løbende at skulle slå op i de 45 sider med tættrykte noter, ca. 20 pr. side, - og så er noterne i bogen ikke engang fortløbende, men begynder forfra for hvert afsnit. Det er direkte læserfjendsk. En række lange noter udgør i sig selv interessante miniafhandlinger; de burde simpelthen stå på den relevante side.

Der er for mange grånussede portrætter og til gengæld ingen af de gode nationalhistoriske billeder, der, som smudsomslaget viser, kunne 
have lyst op. Papir og tryk er så fornemt, at dette sagtens burde kunne have ladet sig gøre. Billedteksterne giver anledning til mange kortfattede, men nyttige personoplysninger.

På s. 41 og 51 er der nogle nyttige figurer til ud over teksten at billedliggøre, hvordan datidens samfunds- og verdensbilledet kan transformeres figurligt og dermed mere forståeligt. Anmelderen kan kun beklage, at forfatteren ikke vedrørende flere sværtbegribelige sammenhænge har forsøgt sig med sådanne figurer - fx havde jeg gerne set Foucaults tankeverden sat på streg.

\section{Afsluttende bemorkninger}

Det er ikke blot en tung bog (ca. 11/2 kg), det er nok så væsentligt også en vagtig og brandaktuel bog, som Ove Korsgaard her har fremlagt, og som jeg efter bedste evne har søgt at trække det for mig væsentlige frem fra. Af radioens temaer formiddag d. 10/8 04 drejede ikke mindre end fire sig om centrale emner for bogen, og blot weekendens aviser i min lille husholdning havde ikke mindre end 20 lange og mellemlange artikler om temaer, som er vægtigt behandlet i bogen. Jeg er dybt imponeret over forfatterens evne til at være både saglig og aktuel og til samtidigt at kunne trække de store linier. Men jeg er selvfølgelig derfor også inspireret til debat og kritik på mange felter. Bogen er ikke nogen lukket afhandling - eller noget med 'at så ved vi det'. Afhandlingen lægger frugtbart op til nye afsøgninger af, hvem vi er, og hvordan og hvorfor vi blev det som enkelt-individer, som folk og som samfund $i$ et løbende og kompliceret samspil mellem indland og udland og mellem ethnos og demos samt gennem stadige og flersidede ændringer og vekselvirkninger mellem sprog, kultur, politik og stat.

Det er dannelseshistorie, som vil noget, og som læseren bliver mere dannet i gammeldags forstand af at tilegne sig.

\section{Noter}

1 Disputatsforsvar den 30.4.2004 på Danmarks Pædagogiske Universitet, opponent ex auditorium var bl.a. Vagn Wåhlin - hvis notater fra forsvarshandlingen indgår i dette indlæg; jf. også O. Korsgaard, "Striden mellem folk og nation", Politiken, kronik 30.4.2004; Jes Fabricius Møller, "Solen staar med Bonden op" (anm. af O.K.s disputats), Weekendavisen, 23-29.4.2004, Bøger, s. 4; Ina Kjøgx Pedersen, "Følelsernes sted", Weekendavisen, 23.-29.4.2004, Udland, s. 8; Asger Brandt, "Et monument over folkets tid", (anm.) Kristeligt dagblad, Kultur, 22.4.2004, s. 6; Uffe Østergård, "Men om 120 år", interview af Anne Hardis, Weekendavisen, 9.-15.7.2004, Indland, s. 2; Henning 
Eichberg, "Imagine all the people ... Folk eller befolkning", JyllandsPosten, kronik, 17.6.2004; Ralf Pittelkow, "Danmark for folket", Jyllands-Posten, 25.4.2004, Indblik, s. 4, boguddrag fra samme: Forsvar for nationalstaten, Lindhardt \& Ringhof, Kbh. 2004.

2 Uffe Østergårds og Ralf Pittelkows indlæg (note 1) er blot nogle få blandt mange, nylige selvbesindelser på, at elitens projekt i politik, økonomi, kultur, på universiteterne og i de store organisationer, LO m.fl. - med at få befolkningen til at elske eller stiltiende at acceptere EU og globaliseringen til afløsning for nationalstaten Danmarks identitets- og tryghedsdannende, folkeligt brede ramme - generelt set er mislykket. Bortset fra befrielsessommeren 1945 har næppe så mange dannebrogsflag vajet over kolonihaverne som nu, når håndboldpigerne, fodboldheltene eller olympiade-deltagerne stiller op til kamp her i 2004, eller som når kronprins Frederik og kronprinsesse Mary gifter sig og rejser riget rundt i folkelig triumf (og endog massivt hyldet af ellers kulturkritiske indvandrergrupper), mens omvendt de nylige valg til det udvidede Europaparlament kun kunne høste minimal interesse $\mathrm{i}$ de brede vælgerskarer - det var i Danmark som i andre EU-lande ikke nogen folkeligt fængende sag.

3 I diverse udgaver af Højskolesangbogen m.fl. steder er sangen normalt forkortet til 7-10 strofer, 15. udg. 1972, nr. 423, har 10 strofer, 16. udg. 1981, nr. 156 bringer 7 strofer; i E. J. Borup og Fr. Schrøder, Haandbog $i$ N. F. S. Grundtvigs Skrifter, II, s. 191-93, Kbh. 1930 er medtaget 8 strofer. Originalen fra Danskeren 30.8.1848, nr. 24, s. 381-84. har 14 strofer, jf. fx den fulde udgave i af sangen bl.a. i P. A. Rosenberg, N. F. S. Grundtvig, Udvalgte Varker, Bd. 1-10, bd. 1, Kbh. 1930 f. og Holger Begtrup, Nik. Fred. Sev. Grundtvigs udvalgte Skrifter, Kbh. 1904-09, bd. IX, s. 139-42. For at læseren kan efterse, hvor mange af Korsgaards temaer om problematikken der findes hos Grundtvig, må den fulde udgave af sangen benyttes; inddrages blot anførte Haandbog $i$... bliver denne iagttagelse endnu tydeligere. Det centrale her er imidlertid ikke at påvise, hvorledes O.K. falder ind i en lang linie af tidligere undersøgelser og begrebsfastlæggelser, men at påpege nogle af de felter, som er nye eller ny-perspektiverede og lovende for det fortsatte arbejde med at forstå, hvem vi danske er som mennesker, og hvordan folk og folkestyre (demokrati) blev så tæt knyttet til hinanden i en langvarig mental og kulturhistorisk og politisk proces.

Jf. s. 33 m.fl. steder.

Jf. s. 11 om definitionsproblematikken. Et forstudie fra 1999 hed Kundskabs-kapløbet. Uddannelse $i$ videnssamfundet, hvor samspillet mellem den industrielle, den demokratiske, den nationale og den pædagogiske revolution blev fremhævet, mens O. K. i disputatsen mere har peget på "samspillet mellem dannelse og den politiske og kulturelle udvikling" med et dannelsesperspektiv på Danmarks historie i perioden. Vedrørende anvendelige definitioner kan det undre, at O. K. ikke fra begyndelsen var klar over, at struktureringsanvendelige begreber i strikt forstand simpelt 
hen ofte ikke findes, når man som $\mathrm{O}$. K. vil beskrive og analysere en langvarig periode eller historisk proces. Forfatteren er da selv en del af en proces om at forstå en proces, dvs. noget, der bevæger og forandrer sig, mens en logisk tilfredsstillende definition som oftest forudsætter, at dens genstand ikke kvalitativt forandrer sig uforudsigeligt eller kaotisk undervejs, for ellers vil definitionen ikke længere passe og årsagsvirkningskæden springer da af cyklen.

6 Fx V. Wåhlin (red.), Historien i kulturhistorien, Århus, 1988, artiklerne (af V. W.) "Fra statshistorie til kulturhistorie", s. 55-85 og "Religion, mentalitet og bevidsthedshistorie", s. 191-234.

7 Korsgaard har s. 3 og s. 652-653 fra sit forfatterskab henvist til mere end 20 bøger og større artikler 1982 ff., der indgår i disputatsens brede baggrundsmateriale og forudgående studier. Bøgerne Kampen om Kroppen (1982) og Kampen om lyset (voksenuddannelsen, 1997) udgør sammen med nærværende arbejde en trilogi, hvorfor anmelderen nødvendigvis må inddrage denne bredere forskningsbaggrund, der optimalt burde omfatte hele forskningsprojektet, 1977 ff., "Voksenuddannelse, folkeoplysning og demokrati"; men det bliver her for omfangsrigt.

8 Oversigten bygger særligt på afhandlingens indledning s. 11-34 og afslutningskapitlet om nutidens situation (s. 469-565) og om begreber, $\mathrm{s}$. 471-73 samt det udmærkede engelske summary s. 566-597; summary udgør - ganske ufolkeligt, fordi det er på engelsk - den sammenfatning og især konklusion, der stærkt savnes, for at læseren kan tjekke, at han nu også har fattet bogens hovedlinie og budskab. Altså kære læser: begynd med at læse bagfra med summary, og gå derefter til nutidens problematik (s. 469-565) og læs først da forfra ind i bogen, så fås nemmest det fyldigste udbytte. Efter nøje læsning af bogens logik tror jeg også, den faktisk er blevet til på den måde: med en undren i 1990'erne over, hvordan vi dog kunne være havnet i elitens udenlandsk-teoretisk baserede, men reelt umulige forkastelse af den danske nationale og kulturelle historie som ren fiktion. Og med det for eliten tankevækkende resultat, at lokal- og slægtshistorikerne samt Dansk Folkeparti næsten har fået monopol på forståelsen og formidlingen af danskhed og opretholdelsen af danske værdier. Endelig har jeg til oversigten inddraget Korsgaards egen aviskronik om bogen (note 1), samt hans $1 / 2$ times mundtlige indledning ved forsvaret.

$9 \quad$ I forbindelse med deltagelse $\mathrm{i}$ det fællesnordiske forskningsprojekt NAFO (Nordisk Arbejdsgruppe for Folkrørelses- og Organisationsforskning) var jeg først i 1980'erne på besøg i undervisningsministeriet i Stockholm, hvor en ledende embedsmand ret stolt fortalte om, hvorledes han ved få opslag kunne redegøre for, hvad skolebørnene på en hvilken som helst lokalitet i landet i 5 . klasse netop i den uge lærte om i historie. Jeg var dybt rystet over en sådan centralisering i detaljen og kunne ikke skjule dette, mens han på den anden side var lige så rystet over min umiddelbare afstandtagen; for hvordan kunne man, dvs. embedsværket, ellers sikre politikerne og befolkningen, at bevillinger og undervisning gav de ønskede resultater. Dagens debat i offentligheden viser, at den 
svenske og europæiske linie, OECDs, er i fremmarch, mens den i Danmark op til ca. 1970 herskende opfattelse af barneskolens lokale fundering både for folkeskolen og friskolen nu i 2004 er hårdt trængt.

10 Omkring 1960 tippede værdien af eksporten fra den agrare sektor til industrisektoren. Her efter år $2000 \mathrm{er}$ fx turismen af større nationaløkonomisk betydning end landbruget, og efter optællingsmetode har kun 3-4 \% af befolkningen deres hovedbeskæftigelse i agrarsektoren.

11 Jf. Vagn Wåhlin, By og land, korrigeret særtryk 1981 af Jørgen Holmgaard (red.), Det grundtvigske bondemiljø (Serie om folkekultur, nr. 4), Ålborg 1981, s 1-73.

12 Netop grundet Finlands anderledes forudsætning under russisk styre og den finske borgerkrig efter 1917 (der reelt fortsattes 1939-44) kunne en nøjere sammenligning på bogens problemfelter med Finland være givtig, fordi den danske og den finske udvikling på mange punkter er endt $\mathrm{i}$ meget parallelle velfærdsstater og i forholden sig til individ over for samfund.

13 Assimilationen og integrationen i Danmark af svenske og polske landarbejdere og russiske jøder før Første Verdenskrig, af Wienerbørn efter denne krig, af finnebørn under og efter Anden Verdenskrig, af ungarere efter 1956 og tjekkoslovaker efter 1968, af vietnamesere efter 1975 m.fl. var reelt ikke noget større administrativt, integrationsmæssigt og økonomisk problem, dels fordi det kun drejede sig om få tusinder, dels fordi stemningen generelt i Danmark var med disse mennesker, og endeligt, fordi vi selv i hovedsagen bestemte, hvem og hvor mange vi tog mod. Begyndende med tyrkisk importeret arbejdskraft fra sidst 1960'erne er denne nye type af tilvandring fra sidst i 1970'erne for alvor blevet samfundsmæssigt væsentligt med økonomiske immigranter og flygtninge fra især den 3. og 4. verdens utallige konflikter - og dermed er en udfordring til, hvem vi er som individer og folk, hvad vore værdier egentlig er og kan holde til, når det virkeligt begynder at koste noget andet end lidt småskillinger og humane ord.

14 De Radikale har anmelderen her et problem med, især efter at tilknytningen til husmandsbevægelsen er ophørt omkring 1970, ved husmændenes uddøen som social-klasse, der har fjernet det folkelige element og efterladt skolelærerne, funktionærerne, de mellemlangt uddannede og de yngre akademikere som kernegrupper for partiet. Men hvad med: 'Det internationale midterparti', jf. partiets nuværende leder, Marianne Jelved, $\mathrm{i}$ et stort indlæg i Jyllands-Posten, Indblik, 8.8.2004, s 3.

15 Musik-industriens engelsk tekstede produktioner og computerindustriens softwareproduktioner og naturvidenskabens matematificering og netværksforbundne og netværksformidlede eksplosivt stigende vidensfond er blot nogle få eksempler på, at den globale landsby faktisk fungerer, men uden nogen identificerbar eller synlig politisk styring - som IT-samfundets nye Helligånd. Ingen ser den og ingen forstår den, før dens virkninger gør sig gældende. 
I Historie på Aarhus Universitet måtte man fra 1980'erne institutionalisere et tvungent basiskursus og en eksaminering i 400 siders Danmarkshistorie (og 1600 siders verdenshistorie), ligesom lærerne selv måtte producere en lærebog - dette hang igen sammen med, at man i gymnasieskolen fra o. 1970 ikke længere gav en sådan sammenhængende basisviden i historie.

17 Læseren kan selv prøve gennem flere gode franske og engelske leksika og ordbøger at følge et så centralt begreb som 'diskurs'; er det 'et system af tanker' eller er det et interagerende 'forløb' af tale og tanker, og hvordan kan nogen person eller gruppe under givne samfundsbetingelser så overhovedet tænke uden for diskursen, når den sætter sig igennem bag ryggen af dem? Og det løser ikke transformationsproblematikken blot at ændre position fra en vidensarkæologisk til en genealogisk (for at undgå at kalde den historisk) sammenhæng og lægge den ud i de sociale handlingers sfærer i spændingsfeltet mellem 'viden' - som diskursivt system - og magt. For nissen flytter igen med, ind i magtbegrebet, som så måtte omdefineres for også at kunne virke dynamisk og konstruktivt forandrende. Oplysningstiden var for anmelderen i Danmark en epoke, hvor magt og viden og medmenneskelighed konstruktivt gik hånd $\mathrm{i}$ hånd. I Viby uden for Århus på højskolemanden Lars Bjørnbaks mindesten står der, Viden er Magt, Uvidenhed er Traeldom; hvad skal vi så med Foucaults og diskursbegrebets snørklede veje? Jeg foretrækker Korsgaards lange fortælling. 